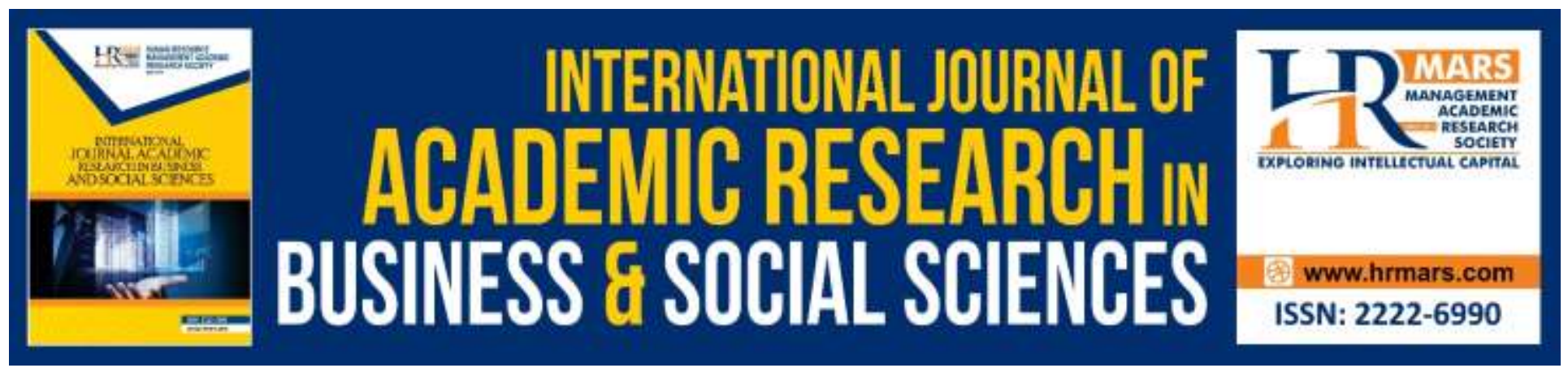

\title{
Examining the Relationship among Learning Self-Efficacy, MOOC-Satisfaction and MOOC-Loyalty of MOOC Learner with Bagozzi's Model
}

Loh Kah Heng, Zaim Azizi Bin Abu Bakar, Nur Ainif Omar, Low Khai Rol

To Link this Article: http://dx.doi.org/10.6007/IJARBSS/v10-i4/7159 DOI:10.6007/IJARBSS/v10-i4/7159

Received: 26 February 2020, Revised: 25 March 2020, Accepted: 10 April 2020

Published Online: 12 April 2020

In-Text Citation: (Heng et al., 2020)

To Cite this Article: Heng, L. K., Bakar, Z. A. B. A., Omar, N. A., \& Rol, L. K. (2020). Examining the relationship among Learning self-efficacy, MOOC-satisfaction and MOOC-Loyalty of MOOC Learner with Bagozzi's Model. International Journal of Academic Research in Business and Social Sciences, 10(4), 609-620.

Copyright: @ 2020 The Author(s)

Published by Human Resource Management Academic Research Society (www.hrmars.com)

This article is published under the Creative Commons Attribution (CC BY 4.0) license. Anyone may reproduce, distribute, translate and create derivative works of this article (for both commercial and non-commercial purposes), subject to full attribution to the original publication and authors. The full terms of this license may be seen

at: http://creativecommons.org/licences/by/4.0/legalcode

Vol. 10, No. 4, 2020, Pg. 509 - 620

http://hrmars.com/index.php/pages/detail/IJARBSS

JOURNAL HOMEPAGE

Full Terms \& Conditions of access and use can be found at http://hrmars.com/index.php/pages/detail/publication-ethics 


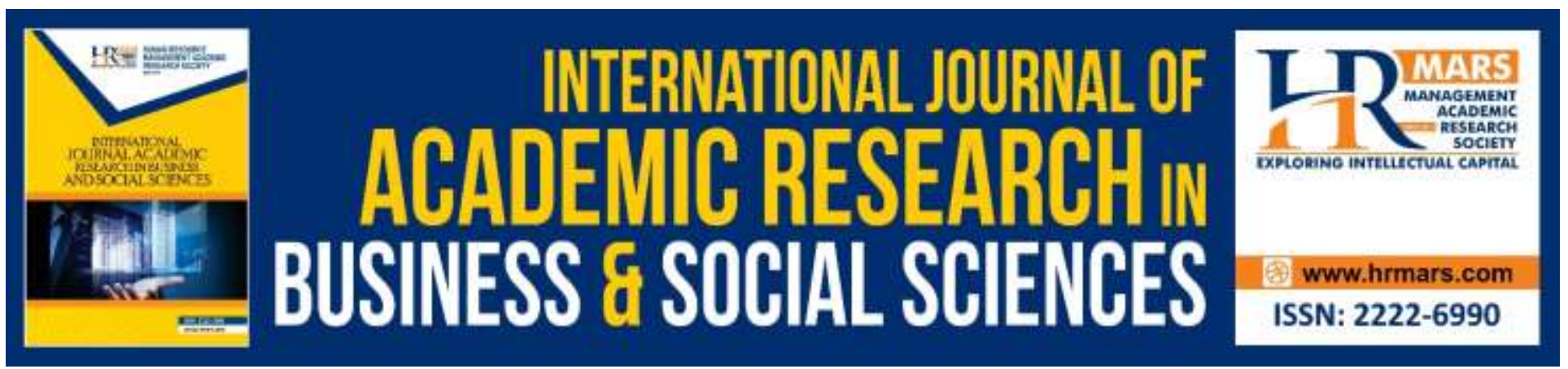

\title{
Examining the Relationship among Learning self- Efficacy, MOOC-Satisfaction and MOOC-Loyalty of MOOC Learner with Bagozzi's Model
}

\author{
${ }^{1}$ Dr Loh Kah Heng, ${ }^{1}$ Zaim Azizi Bin Abu Bakar, ${ }^{1}$ Nur Ainif Omar, ${ }^{2}$ \\ Low Khai Rol \\ ${ }^{1}$ School of Liberal Arts and Sciences, Taylor's University, Malaysia, ${ }^{2}$ FairView International School, \\ Subang, Malaysia
}

\begin{abstract}
The objective of this research is to address the gaps in the literature by examining the relationship among Learning self-efficacy, MOOC-satisfaction and MOOC- Loyalty of the creditbearning MOOCs at Taylor's University. A total 952 Taylor's University students responded to the online survey, 757 students from the August 2017 semester while 195 students from March 2018 Semester. The online questionnaire included 10-item of learning self-efficacy in MOOC, 6-item of MOOC-satisfaction, and 5-item of MOOC-Loyalty. It also included another 2 factors which affected the self-efficacy and satisfaction: 9-item on Ease of learning in MOOC and 5-item on Quality of MOOC content. Reliability test was performed and reported the Cronbach's alphas for students' Learning self-efficacy in MOOC, MOOC-satisfaction and MOOC-Loyalty were 0.979, 0.959, 0.964 respectively while Cronbach alpha for Ease of learning in MOOC and Quality of MOOC content were 0.962 and 0.964 respectively. Pearson correlation analysis was performed to obtain the correlation coefficient between pair of variables among all the variables. The results of zero order correlation analysis showed a strong positive correlation between the predictors and outcome variables. However, a higher order partial correlation was also performed and results showed that MOOC-satisfaction is an intervening variable which mediate the relationship between Learning self-efficacy and MOOCLoyalty. The research findings provided positive impact to lecturers who plan to convert from traditional teaching pedagogy to MOOC mode as Malaysian students have higher degree of MOOCloyalty and they were in favor of continuing to take up the credit bearing MOOC throughout their study at Taylor's university or after graduating. Besides, it also alarmed the university administrator to provide the best infra-structure for the MOOC platform and best quality of MOOC content so as to raise the MOOC-satisfaction which would enhance the MOOC-loyalty.
\end{abstract}

Keywords: Massive Open Online Course (MOOC), MOOC-satisfaction, MOOC-loyalty, Learning Selfefficacy 
INTERNATIONAL JOURNAL OF ACADEMIC RESEARCH IN BUSINESS AND SOCIAL SCIENCES Vol. 10, No. 4, April, 2020, E-ISSN: 2222-6990 @ 2020 HRMARS

\section{Introduction}

"MOOCs here, MOOCs there and MOOCs are everywhere" has become one of the common phenomenon in higher educational Institutions (HEI) globally for several reasons. There must be MOOCs somewhere for everyone. There are various reasons for HEl to offer MOOCs, among these reasons are 1) extending reach and access, 2) building and maintaining brand, 3) improving economics by reducing costs or increasing revenues, 4) improving educational outcomes, 5) innovation in teaching and learning, and 6) conducting research on teaching and learning (Holland, 2014).

MOOCs have drawn attention of educators and educational providers since 2008 with the inception of cMOOC by the young researchers George Siemens and Steven Downes. They are often called the founders of MOOCs. In 2011, another version known as XMOOCs which emphasize on individual learning was introduced. A number of companies such as: Udacity, EdX and Coursera have started to run the xMOOCs. The educational landscape particularly in the higher education has changed drastically since the inceptions of XMOOCs. Class Central's MOOC report (2018) has reported that there are more than 900 Universities in the world had announced or launched 11400 MOOCs, with around 2000 new courses added to the list in 2018. Class central (2018) also reported that there are 20 million new learners signed up for at least one MOOC in 2018, which make the number of learners to a total of 101 million since 2012.

It is undeniable fact that the educational landscape has been changed dramatically due to the mushrooming of XMOOCs in the HEls globally. According to Balaii (2013), MOOC is increasingly gaining its popularity in many developing countries which has well developed digital infrastructure in area of metropolitan and universities. The paradigm shift of social networking relying heavily on information communication technology and ubiquitous computing are beginning to set a profound impact on teaching and learning strategy, and most prominently, on the evolution of new educational landscape offer to our Millennial learners. With this new paradigm of open and online education, learning and knowledge acquisition is no longer restricted and confined within walls and classrooms. Learning can now take place anytime, anywhere in the convenient of one's own pace as long as there is penetration of radio waves and coverage of WiFi with the aid of online learning. With this development, MOOCs have drawn attention of researchers and stakeholders in higher education sector. Mawaddah (2018) suggested a conceptual model to identify the factors that determine users to continue to select modules offer in MOOC for their learning platform. The model demonstrates the relationship between usefulness, enjoyment, interactivity and openness with MOOCs continuance intention. The research model focused on post adoption usage by examining the continuance intention of Malaysia MOOCs system. Continuance intention is somehow related to MOOC-loyalty as Lee \& Kwon (2011) stated that continuance intention describes about user's decision to continue use a specific technology that users have already using it. By far, the model has yet to be tested with concrete data. Anderson (2003) investigated the impact of satisfaction on loyalty in the context of electronic commerce. The research indicates that e-satisfaction has impacted e-loyalty, and the relationship is moderated by some other business factors such as trust and perceived value. Even though the research is not directed to MOOC adoption, however its research constructs such as esatisfaction and e-loyalty can be replicated in MOOC-satisfaction and MOOC-loyalty with academic factor such as learning self-efficacy, ease of learning and quality of MOOC contents. Polites (2012) proposed a research model on the relationship between e-satisfaction and websites stickiness (another term related to e-loyalty) grounded on Bagozzi's 1992 framework of the self-regulation of 
attitudes, intentions, and behavior. His research focused on consumer perceptions of satisfaction with, and loyalty toward, the information technology (IT) artifact (website) itself. The results obtained generally support the proposed model, indicating a statistical weak relationship between the e-satisfaction and e-loyalty (Site stickiness). Cui (2018) explored the relation between multidimensional self-efficacy and MOOCs continuous learning willingness by building his research model based on Expectation Confirmation Model- Information Tecgnology proposed by Bhattacherjeethe (2001) who stated that success of IS not merely depended on initial use, the key was the continuous use (which is similar to e-loyalty).

The waves of MOOCs have started to propagate into Malaysia since the inception of cMOOCs in 2008. There are $11 \mathrm{HEIs}$ in Malaysia offer more than $50 \%$ of their courses online (Norazah, Amin, and Zaidan, 2011). The study reports that $13.8 \%$ lecturers provide more than $80 \%$ online learning materials and that $44.6 \%$ of students prefer to read materials uploaded by their lecturers. The findings also show that students' preference for online courses is very encouraging. In fact, lecturers also agree that the integration of e-learning into their courses has benefited students. In general, it clearly shows that MOOCs are accepted by lecturers and students of HEls as an effective means of communication and teaching and learning. Malaysia has become the first country in the world to implement creditbearing MOOCs for university students to enroll to the compulsory courses in its Public Universities since 2014 and develop a national policy on credit recognition for the MOOCs in 2016. Since then, many public and private universities in Malaysia have started the MOOC initiatives in general studies modules on a partial implementation basis. Many public universities have claimed to start the piloted MOOC initiatives for the general studies modules which include Hubungan Etnik (Ethnic Relation) and TITAS. However, the initiative to offer MOOC delivery to the two modules in the public universities are conducted "as a blended learning course - where about $30 \%$ of the course was conducted in MOOCs while the remaining percentage was carried out according to course instructors" (Nordin, et. al., 2015).

Taylor's University is a top ranking private university in Malaysia which has begun to develop modules in MOOC since 2013. It is the first University in Malaysia to offer MOOCs with $100 \%$ online delivery to replace the traditional face to face approach to its two general study modules in 2016. The two compulsory general studies modules are Hubungan Ethnik (Ethnic Relations) and Tamadun Islam dan Tamadun Asia, TITAS (Islamic Civilization and Asia Civilization). These two modules have large enrolment, each module has more than 1200 students for each semester and all Malaysia students need to undertake and pass these two modules before they receive their degree.

\section{Purpose of Study \\ Problem Statement}

Taylor's University has implemented its new curriculum in 2018, known as Taylor's Curriculum Framework (TCF), which aims to future-proof graduates to be ready for the Fourth Industrial Revolution. TCF helps to prepare graduates to be ready in different jobs in the future by training them to be able to learn for themselves in a life-long learning manner in the future. To achieve this goal, the TCF adopts a 'teach less, learn more' philosophy where face-to-face lectures will be gradually reduced from the first to third year to build students' independent self-learning and peer learning abilities. More and more modules are turning into credit bearing MOOCs. This effort will train graduates to go online and take a $\mathrm{MOOC}$ course in preparation to move from one job to another 
job in future. However, despite the fact that today's kids are born digital-born into a media rich, networked world of infinite possibilities, their formal education and learning environment prior to enrolling into university are still "passive and in teaching paradigm" and conducted in the traditional face to face approach. University students may face problems with such a drastic change from a conventional face to face education environment into the new learning paradigm, such as losing confidence and not satisfied in learning, which may lead to the anxiety or denial to learn MOOCs in future. It is important to note that MOOC-loyalty and MOOC-satisfaction play an important role in the successful future adoption of learning via MOOCs platform.

In response to these problems, this research proposes to examine relationship among learning selfefficacy, MOOC-satisfaction and MOOC-Loyalty of MOOC learners at Taylor's University.

The objective of this research was to address the gaps in the literature by examining the relationship among Learning self-efficacy, MOOC-satisfaction and MOOC- Loyalty of the credit-bearning MOOCs at Taylor's University.

\section{Theoretical Framework}

This research adapts and adopts Bagozzi's (1992) "self-regulatory process" framework which stimulate intentions, cause enactment of behavior and lead to goal attainment. The process acts in monitoring appraisal and coping activities that translate attitudes into intention (appraisal process), intentions into actions (emotional reaction) and leading to goal attainment (coping responses). The emotional self-regulation of the attitude intention relationship Model (include "self-regulatory process" framework) is represented as shown in figure 1. This framework conceptualize attitude as an evaluative appraisal of the consequences of action. The appraisal is either favorable or unfavorable. Following the appraisal, intentions are expected to emerge with the evaluations results. To form an intention to act requires a desire to perform the act, together with the presence of selfefficacy. Positive or negative reaction are expected to occur depending on the appraisal outcomes. The emotional reaction in turn, induce coping activities. These coping activities again includes motivation to avoid, relieve, change in the negative aspect or maintain the satisfaction, share positive outcomes with others or savor the experience in the positive aspects.

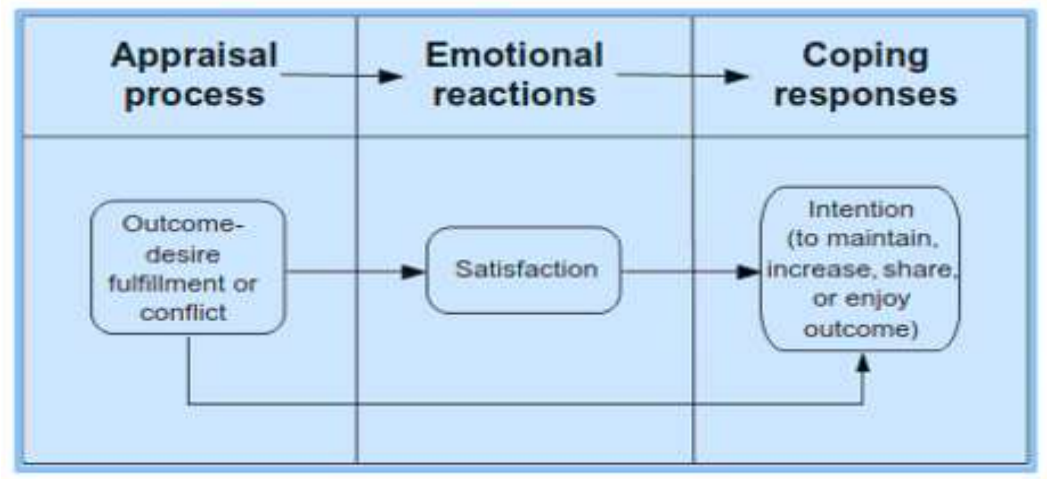

Figure 1: Emotional self-regulation Model (Bagozzi ,1992).

Figure 2 shows the proposed research model of this study adapted and modified from Bagozzi's (1992) emotional self-regulation of the attitude intention relationship Model. The appraisal process 
INTERNATIONAL JOURNAL OF ACADEMIC RESEARCH IN BUSINESS AND SOCIAL SCIENCES Vol. 10, No. 4, April, 2020, E-ISSN: 2222-6990 @ 2020 HRMARS

in this model involves the learning self-efficacy which addresses the evaluation of resources in MOOC with regards to quality of $\mathrm{MOOC}$ content and Ease of learning. Consider a MOOC learner achieves a goal or experiences a pleasant event, with high level of learning self-efficacy, an outcome-desire fulfillment is said to occur. This experience will lead to MOOC-satisfaction. Specific intentions probably will emerge to take step to maintain or increase MOOC-satisfaction by sharing experience with others. Thus, the specific coping responses will depend on the particular emotion, and the degree of learning self-efficacy characteristic of the outcome-desire unit. As a results, MOOC learner will choose to take up another credit-bearing MOOC modules in the university or after graduation while changing for a new job. This is translated as MOOC-Loyalty.

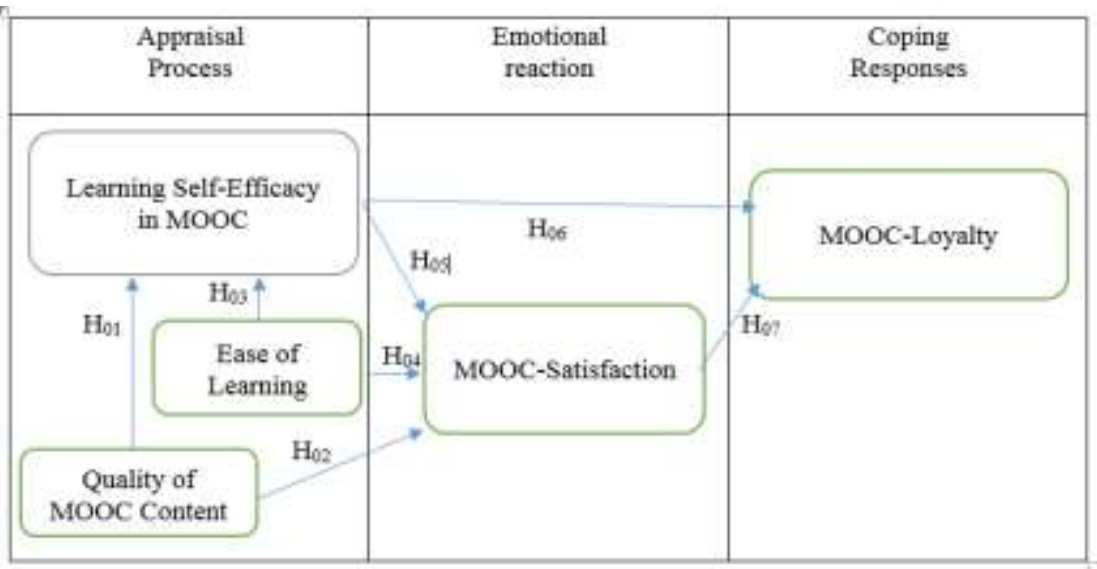

Figure 2: Proposed research model to Investigating relationship among Learning self-efficacy, MOOC-satisfaction and MOOC- Loyalty

\section{Definitions}

\section{Learning self-efficacy in MOOC}

Bandura (1994) defines Self-efficacy as people's beliefs about their capabilities to produce expected outcomes. Self-efficacy is highly context specific. In this study, Learning self-efficacy in MOOC refers to learners' confidence in learning a module in the MOOC environment, with regards to the ease of learning and quality of the content presented in MOOC.

\section{MOOC-satisfaction}

Satisfaction is essential to any form of service provider. Oliver (1997) defined satisfaction as "the summary of psychological state resulting when the emotion surrounding disconfirmed expectations is coupled with a consumer's prior feelings about the consumer experience". In e-commerce environment, e-satisfaction is defined as the contentment of the customer with respect to his or her prior purchasing experience with a given electronic commerce firm. MOOC-Satisfaction in this study refers to learner's satisfaction with regards to ensuring his effective learning and increases his competence which would guarantee his proper function in an online or MOOC learning environment (Muylle, et.al, 2004).

\section{MOOC-Loyalty}

In business world, loyalty is the important factor which determine the growth or maintenance of business transaction or continuous support by consumers. Brand loyalty is defined as "the preferential, attitudinal and behavioral response toward one or more brands in a product category 
expressed over a period of time by a consumer" (Engel, Kollat, and Blackwell, 1982). In e-business, e-loyalty is defined as the customer's favorable attitude toward an electronic business resulting in repeat buying behavior (Anderson, 2003). In e-learning or MOOC environment, MOOC-loyalty is defined as MOOC learner's favorable attitude toward learning a module in a MOOCs environment resulting in $\mathrm{MOOC}$ learner to repeatedly enroll to another credit-bearing $\mathrm{MOOC}$ in the university or after graduation while changing for a new job.

\section{Null Hypotheses}

A set of null hypotheses were formulated based on the research model adapted from the emotional self-regulation Model (Bagozzi, 1992).

$\mathrm{H}_{01}$ : There is no statistical significant positive correlation between Quality of MOOC content and students' Learning Self-efficacy in MOOC.

$\mathrm{H}_{02}$ : There is no statistical significant positive correlation between Quality of MOOC content and students' MOOC satisfaction.

$\mathrm{H}_{03}$ : There is no statistical significant positive correlation between Ease of learning in MOOC and students' Learning Self-efficacy in MOOC.

$\mathrm{H}_{04}$ : There is no statistical significant positive correlation between Ease of learning in MOOC and students' MOOC satisfaction.

$\mathrm{H}_{05}$ : There is no statistical significant positive correlation between Students' Learning Self-efficacy in MOOC and students' MOOC satisfaction.

$\mathrm{H}_{06}$ : There is no statistical significant positive correlation between Students' Learning Self-efficacy in MOOC and students' MOOC Loyalty.

$\mathrm{H}_{07}$ : There is no statistical significant positive correlation between Students' MOOC satisfaction and students' MOOC Loyalty.

\section{Method}

\section{Study Design}

The present study adopted the quantitative approach and correlational design to explore the relationship among students' Learning self-efficacy in MOOC, MOOC-satisfaction and MOOC-Loyalty

\section{Sample}

A convenient sample of students was used to investigate the relationship among the variables. 952 Taylor's University students responded to the online survey, 757 students from the August 2017 semester while 195 students from March 2018 Semester. These students were studying in various faculties. There were 458 students enrolled to the Tamadun Islam and Tamadun Asia or TITAS and 493 students enrolled to Hubungan Etnik or HE. The sample comprised of 502 female students and 450 male students. The age of the students ranges from 19 year old to 22 years old.

\section{Procedure}

This study was carried out from August 2017 to July 2018 for a period of 2 semesters at Taylor's University. Duration of each semester were 14 weeks. The TITAS and HE modules were conducted via MOOC mode with $100 \%$ online and only offered to Malaysian students. They have completed 12 years of formal education and one to two years of Pre tertiary education prior to their enrolment into the degree program at Taylor's University. 
INTERNATIONAL JOURNAL OF ACADEMIC RESEARCH IN BUSINESS AND SOCIAL SCIENCES Vol. 10, No. 4, April, 2020, E-ISSN: 2222-6990 @ 2020 HRMARS

\section{TITAS and HE via MOOC at Taylor's University}

The two modules, TITAS and HE fall under the category of general studies modules and are mandatory for all Malaysian students pursuing Bachelor's Degree.

TITAS modules recognizes the benefits of the ancient civilization, the advantages and disadvantages of the past and present to devise future strategy while HE module focuses on the study of the basic concepts of ethics relations.

These two modules are conducted with an initial two hours of face to face briefing session in Week 1 where the lecturer concern provided a thorough explanation of the modules. Students were guided to register and use the OpenLearning platform and Taylor's Moodle Platforms during this face-toface session. Students were required to participate in online learning via MOOC platform in a weekly basis. They were responsible to complete the exercises, watched the videos and conducted selfstudy. The online learning via MOOC replaced the face-to-face lessons throughout the semester. The weekly activities (checkpoints) were treated as the attendance for this virtual classes. It was mandatory for students to complete $100 \%$ of attendance. Two times of YouTube Live sessions were also conducted by the lecturer in $6^{\text {th }}$ and $12^{\text {th }}$ week of the semester to have live discussion with the students regarding their assignments and projects. These live discussion sessions were recorded and uploaded to the MOOC platform for students to review.

\section{Data Collection}

The link to self-developed online survey questionnaire in Google form was posted on the Taylor's MOOC platform for students to response to the survey questions at the end of the semester. The online questionnaire includes 10-item of learning self-efficacy in MOOC, 6-item of MOOCsatisfaction, and 5-item of MOOC-Loyalty. It also includes another 2 factors which affect the selfefficacy and MOOC-satisfaction, that is 9-item on Ease of learning in MOOC and 5-item on Quality of MOOC content. All these items to measure each construct are expressed in 7 point Likert scale of self-report measure rated on a scale varying from 1 being "strongly disagree to 7 being "strongly agree". Examples of the items on learning self-efficacy are: Taking MOOCs modules enable me to 1. Organise my activities so that I can meet the course deadlines, 2. Understant new information, even on a topic that does not interest me very much. Examples for quality of course contents are: The content of MOOCs modules is: 1 . accurate and appropriate; 2 . Clear and at the right level of detail. Examples of Ease of learning are: Taking MOOCs is: 1. Easy to follow in learning the module, 2. Effortless in learning the module. Examples of MOOC-satisfaction are: I feel I am getting my money's worth by taking MOOCs Modules, 2. Overall, I am satisfied with the MOOCs at Taylor's University. Examples of MOOC-loyalty are: 1. I am likely to take any MOOCs offer by Taylor's University, 2. I will recommend other people to take modules conducted in MOOC mode.

The reliability test was performed and the Cronbach's alphas for the three variables, students' Learning self-efficacy in MOOC, MOOC-satisfaction and MOOC-Loyalty are 0.979, 0.959, 0.964 respectively while Cronbach alpha for Ease of learning in MOOC and Quality of MOOC content are 0.962 and 0.964 respectively. 
INTERNATIONAL JOURNAL OF ACADEMIC RESEARCH IN BUSINESS AND SOCIAL SCIENCES

Vol. 10, No. 4, April, 2020, E-ISSN: 2222-6990 @ 2020 HRMARS

\section{Data Analysis}

The data collected from the online questionnaire which was tabulated in the google sheets were converted into SPSS worksheet IBM SPSS, version 20. All the null hypotheses were tested using the statistical analysis.

\section{Results and Discussion}

\section{Hypotheses Testing}

Pearson's Product Moment Correlation Coefficient were computed to test the relationship among all the variables in this study. Table 1 displays the results which had indicated that all the null hypotheses were rejected in favor of the alternative hypotheses, The results showed that content quality of $\mathrm{MOOC}$ and ease of learning are important factors which influence the learning self-efficacy and MOOC satisfaction, and the learning self-efficacy, MOOC satisfaction and MOOC-loyalty are strongly and positively correlated to each other.

Table 1: Results of Testing Hypotheses with Pearson's

Correlation Coefficient

\begin{tabular}{|c|c|c|}
\hline $\mathrm{H}_{0}$ & $\begin{array}{l}\text { Results (Pearson's } \\
\text { correlation analysis) }\end{array}$ & Alternative Hypotheses \\
\hline $\mathrm{H}_{01}$ & $\begin{array}{l}\mathrm{R}(952)=0.895, \mathrm{p}<0.01 \text {, two- } \\
\text { tailed } \\
\text { Reject } \mathrm{H}_{01} \text { in favour of } \mathrm{H}_{1}\end{array}$ & $\begin{array}{l}\mathrm{H}_{1} \text { : There is a statistically significant } \\
\text { strong positive correlation between } \\
\text { Quality of MOOC content and } \\
\text { students' Learning Self-efficacy in } \\
\text { MOOC. }\end{array}$ \\
\hline $\mathrm{H}_{02}$ & $\begin{array}{l}\mathrm{R}(952)=0.830, \mathrm{p}<0.01 \text {, two- } \\
\text { tailed } \\
\text { Reject } \mathrm{H}_{02} \text { in favour of } \mathrm{H}_{2}\end{array}$ & $\begin{array}{l}\mathrm{H}_{2} \text { : There is a statistically significant } \\
\text { strong positive correlation between } \\
\text { Quality of MOOC content and } \\
\text { students' MOOC satisfaction. }\end{array}$ \\
\hline $\mathrm{H}_{03}$ & $\begin{array}{l}\mathrm{R}(952)=0.876, \mathrm{p}<0.01 \text {, two- } \\
\text { tailed } \\
\text { Reject } \mathrm{H}_{03} \text { in favour of } \mathrm{H}_{3}\end{array}$ & $\begin{array}{l}\mathrm{H}_{3} \text { : There is a statistically significant } \\
\text { strong positive correlation between } \\
\text { Ease of learning in MOOC and } \\
\text { students' Learning Self-efficacy in } \\
\text { MOOC. }\end{array}$ \\
\hline $\mathrm{H}_{04}$ & $\begin{array}{l}\mathrm{R}(952)=0.836, \mathrm{p}<0.01 \text {, two- } \\
\text { tailed } \\
\text { Reject } \mathrm{H}_{04} \text { in favour of } \mathrm{H}_{4}\end{array}$ & $\begin{array}{l}\mathrm{H}_{4} \text { : There is a statistically significant } \\
\text { strong positive correlation between } \\
\text { Ease of learning in MOOC and } \\
\text { students' MOOC satisfaction. }\end{array}$ \\
\hline $\mathrm{H}_{05}$ & $\begin{array}{l}\mathrm{R}(952)=0.862, \mathrm{p}<0.01, \text { two- } \\
\text { tailed } \\
\text { Reject } \mathrm{H}_{05} \text { in favour of } \mathrm{H}_{5}\end{array}$ & $\begin{array}{l}\mathrm{H}_{5} \text { : There is a statistically significant } \\
\text { strong positive correlation between } \\
\text { Students' Learning Self-efficacy in } \\
\text { MOOC and students' MOOC } \\
\text { satisfaction. }\end{array}$ \\
\hline
\end{tabular}


INTERNATIONAL JOURNAL OF ACADEMIC RESEARCH IN BUSINESS AND SOCIAL SCIENCES Vol. 10, No. 4, April, 2020, E-ISSN: 2222-6990 @ 2020 HRMARS

\begin{tabular}{|l|l|l|}
\hline $\mathrm{H}_{06}$ & $\begin{array}{l}\mathrm{R}(952)=0.777, \mathrm{p}<0.01, \text { two- } \\
\text { tailed } \\
\text { Reject } \mathrm{H}_{06} \text { in favour of } \mathrm{H}_{6}\end{array}$ & $\begin{array}{l}\mathrm{H}_{6} \text { : There is a statistically significant } \\
\text { strong positive correlation between } \\
\text { Students' Learning Self-efficacy in } \\
\text { MOOC and students' MOOC Loyalty. }\end{array}$ \\
\hline $\mathrm{H}_{07}$ & $\begin{array}{l}\mathrm{R}(952)=0.878, \mathrm{p}<0.01, \text { two- } \\
\text { tailed } \\
\text { Reject } \mathrm{H}_{01} \text { in favour of } \mathrm{H}_{1}\end{array}$ & $\begin{array}{l}\mathrm{H}_{1}: \text { There is a statistically significant } \\
\text { strong positive correlation between } \\
\text { Students' MOOC satisfaction and } \\
\text { students' MOOC Loyalty. }\end{array}$ \\
\hline
\end{tabular}

According to Cohen's (1988) guidelines for interpreting strength of association, the results of this zero order correlation analysis show a strong positive correlation between the predictor and outcome variables.

However, the researcher suspected that the learning self-efficacy has direct impact on the MOOCloyalty. Thus, a higher order partial correlation was also performed to determine if the Learning selfefficacy was correlated with the MOOC-Loyalty not because it exerted some direct effect upon the MOOC-Loyalty, but because it caused changes in MOOC-satisfaction, and then the MOOCsatisfaction caused changes in MOOC-Loyalty. It is essential to determine if MOOC-satisfaction is an intervening variable known as mediator which mediate the relationship between Learning selfefficacy and MOOC-Loyalty.

The four step approach proposed by Baron and Kenny (1986) was used to test the mediation effects of MOOC-satisfaction on Learning self-efficacy in MOOC in predicting MOOC-loyalty. The zero order correlations among the variables in the first three steps were found to be significant as evident in $\mathrm{H}_{05}, \mathrm{H}_{06}$ and $\mathrm{H}_{07}$. However, In step 4, a first order partial correlation was performed by controlling the MOOC-satisfaction, and found that there was no statistically correlation between Learning selfefficacy in MOOC and MOOC-loyalty, with the results from Partial Corr: $R(952)=0.081$; $p=0.012$. This result indicated that MOOC-satisfaction was a complete mediator of the relationship between learning self-efficacy in MOOC and MOOC-loyalty.

\section{Conclusion}

The strength of association among the variables under study, namely, students' Learning self-efficacy in MOOC, MOOC-satisfaction, and MOOC-Loyalty at Taylor's University were determined using Pearson's Correlation coefficient in SPSS. A significant high correlation were obtained between students' Learning self-efficacy in MOOC and MOOC-satisfaction $(R(952)=0.836, p<0.01)$, between students' Learning self-efficacy in MOOC and students' MOOC Loyalty $(R(952)=0.777, p<0.01)$, and between students' MOOC satisfaction and students' MOOC Loyalty $(R(952)=0.878, p<0.01)$. Besides, the relationship between the other two factors affecting the learning self-efficacy and MOOC-satisfaction, i.e Ease of learning in MOOC and Quality of MOOC content were also determined. Significant high correlation were also obtained between Quality of MOOC content and students' Learning Self-efficacy in $\operatorname{MOOC}(R(952)=0.895, p<0.01)$, between Quality of MOOC content and students' MOOC satisfaction. $(R(952)=0.830, p<0.01)$; between Ease of learning in MOOC and students' Learning Self-efficacy in $\operatorname{MOOC}(R(952)=0.876, p<0.01)$; between Ease of learning in MOOC and students' MOOC satisfaction. $(R(952)=0.836, p<0.01)$. 
The two modules have been conducted for at least two semesters in MOOC mode before this study was carried out. Improvement on the quality of contents and easiness in learning have been done after obtaining feedbacks from the students, thus this might have led to the higher rating on all the measurable variables, particularly on the MOOC-satisfaction and MOOC-loyalty. This may contribute to strong association among the three constructs, learning self-efficacy, MOOC-satisfaction and MOOC-loyalty.

The results from Pearson's zero order correlation suggested that all the null hypotheses were rejected in favor of their respective alternative hypotheses as each pair of variables showed significant positive correlation. However, with the testing of mediation effect, MOOC-satisfaction has been identified as the complete mediator which intervened the relationship between learning selfefficacy and MOOC-loyalty. The test of mediating effect has proven the doubt that the author have had on the high correlation among the three variables. This result imply that MOOC-loyalty can be strengthen by enhancing the MOOC-satisfaction.

The results of this study have complied with the proposed research framework. During the appraisal process, students assessed quality of $\mathrm{MOOC}$ content and Ease of learning which affect the learning self-efficacy and lead to emotional reaction known as MOOC-satisfaction. To cope with MOOCsatisfaction, specific intentions known as MOOC-loyalty occur, which may be characterized in the subsequent activity such as taking up another credit-bearing MOOC modules in the university or after graduation while changing for a new job. In other words, the higher the MOOC-loyalty rated by the learners, the more likely that they will be in favor of choosing MOOCs as their mode for future learning or a habit of life-long learning.

\section{Suggestion for Future Study}

To date, there are only two academic modules as mentioned in this study conducted in $100 \%$ online delivery in MOOC mode. However, there are a few other MOOC modules conducted in less than $80 \%$ of online delivery, and these modules are termed as Private Open Online Course (POOC). The same questionnaires may be adapted to study on the POOC modules such as Malaysian studies and other modules offer at Taylor's university on the relationship among the three constructs, using the same framework or another theoretical framework so as to investigate if the same results can be obtained. To improve the rigorous and robustness of this type of study, further research can be conducted to look into several issues such as the relationship among learners' acceptance of MOOC and usability, usefulness, loyalty, satisfaction and ease of use based on Technology Acceptance Model (TAM).

\section{References}

Anderson, R. E., \& Srinivasan, S. S. (2003). E-satisfaction and e-loyalty: A contingency framework. Psychology and Marketing, 20(2), 123-138.

Balaji, V. (2013). MOOC in developing countries: a case study from India. Pan-Commonwealth Forum 7 (PCF7)

Bagozzi, R. P. (1992). The Self-Regulation of Attitudes, Intentions, and Behavior. Social Psychology Quarterly, 55(2), 178.

Bandura, A. (1994). Self-Efficacy. Encyclopedia of human behavior (Vol. 4, pp. 71-81). New York: Academic Press,

Baron, R. M., \& Kenny, D. A. (1986). The moderator-mediator variable distinction in social psychological research: Conceptual, strategic, and statistical considerations. Journal of Personality and Social Psychology, 51(6), 1173-1182. 
INTERNATIONAL JOURNAL OF ACADEMIC RESEARCH IN BUSINESS AND SOCIAL SCIENCES

Vol. 10, No. 4, April, 2020, E-ISSN: 2222-6990 @ 2020 HRMARS

Bhattacherjee, A. (2001). Understanding Information Systems Continuance: An ExpectationConfirmation Model. MIS Quarterly, 25(3), 351. doi:10.2307/3250921

Class Central. (2019). By The Numbers: MOOCs in 2018 ? Retrieved from https://www.classcentral.com/report/mooc-stats-2018/

Cui, Z., Yu, Q., Jiang, C., \& Chen, M. (2019). Exploring Factors Influencing MOOC Continuous Learning Willingness Based on Self-efficacy. DEStech Transactions on Social Science, Education and Human Science, (icssm). doi:10.12783/dtssehs/icssm2018/27123

De La Fuente, G. Á., \& Alarcón, C. D. (2017). MOOC: medición de satisfacción, fidelización, éxito y certificación de la educación digital[MOOCs: measuring satisfaction, loyalty, success and certification of digital education]. RIED. Revista Iberoamericana de Educación a Distancia, 20(1), 105. doi:10.5944/ried.20.1.16820

Hollands, F. M., \& Tirthali, D. (2014). Why do Institutions Offer MOOCs? Online Learning, 18(3). doi:10.24059/olj.v18i3.464

Judd, C. M., \& Kenny, D. A. (1981). Process Analysis. Evaluation Review, 5(5), 602-619. doi:10.1177/0193841x8100500502

Lee, Y., \& Kwon, O. (2011). Intimacy, familiarity and continuance intention: An extended expectation-confirmation model in web-based services. Electronic Commerce Research and Applications, 10(3), 342-357. doi:10.1016/j.elerap.2010.11.005

Mackinnon, D. P., Lockwood, C. M., Hoffman, J. M., West, S. G., \& Sheets, V. (2002). A comparison of methods to test mediation and other intervening variable effects. Psychological Methods, 7(1), 83-104. doi:10.1037/1082-989x.7.1.83

Mawaddah, M. (2018). Factors affecting MOOCS continuance intention in Malaysia: A proposed conceptual framework. Journal of Humanities, Language, Culture and Business (HLCB) Vol. 2: No. 7,61-72

Muylle, S., Moenaert, R., \& Despontin, M. (2004). The conceptualization and empirical validation of web site user satisfaction. Information \& Management, 41(5), 543-560. doi:10.1016/s03787206(03)00089-2

Norazah, M. N., Amin, M. E., \& Zaidan, A. B. (2011). Integration of E-Learning in Teaching \& Learning in Malaysia Higher Education Institutions. In M.A. Embi (Eds). E-Learning in Malaysian Higher Education Institutions: Status, Trend \& Challenges. Malaysia: Ministry of Higher Education, 81-98.

Nordin, N., Norman, H., \& Embi, M. A. (2016). Technology Acceptance of Massive Open Online Courses in Malaysia. Malaysian Journal of Distance Education,17(2), 1-16. doi:10.21315/mjde2015.17.2.1

Polites, G. L., Williams, C. K., Karahanna, E., \& Seligman, L. (2012). A Theoretical Framework for Consumer E-Satisfaction and Site Stickiness: An Evaluation in the Context of Online Hotel Reservations. Journal of Organizational Computing and Electronic Commerce, 22(1), 1-37. doi:10.1080/10919392.2012.642242

Richard, L. O. (2010). Satisfaction: A Behavioral Perspective on the Consumer. Armonk, NY: M.E. Sharpe 2010. , ISBN: 978-0-7656-1770-5 2nd ed. Journal of Service Management, 21(4), 549551. doi:10.1108/09564231011066132 